\title{
Feeding ecology of deep-sea seastars (Echinodermata: Asteroidea): a pigment biomarker approach
}

\author{
Kerry L. Howell*', David S. M. Billett, Paul A. Tyler, Russell Davidson \\ Southampton Oceanography Centre, European Way, Southampton SO14 3ZH, UK
}

\begin{abstract}
Resource partitioning and utilisation of phytodetritus by the abyssal mud-ingesting seastars Styracaster chuni and Hyphalaster inermis were investigated using pigment biomarker analysis. The chlorophyll and carotenoid pigment composition of the stomach content was examined using high-pressure liquid chromatography. No significant differences were observed between the composition of pigments in the 2 species. Both asteroid species utilise the same phytodetrital resource with no apparent partitioning of that resource. Analysis of specific biomarker pigments together with evidence from previous studies suggest that both species ingest small chlorophytes, cryptomonads, cyanobacteria, coccoliths and diatoms as part of the phytodetrital component of their diet. Phytodetrital material itself is not thought to be an important food source for $H$. inermis or $S$. chuni.
\end{abstract}

KEY WORDS: HPLC · Pigments · Diet · Asteroidea · Deep-sea · Resource partitioning

Resale or republication not permitted without written consent of the publisher

\section{INTRODUCTION}

The diets of many deep-sea animals are largely unknown. Observations of feeding behaviour and in situ feeding experiments require the use of sophisticated technologies such as remotely operated vehicles and submersibles, which are both scarce and expensive to use. In addition, traditional methods of investigating diet, such as stomach content analysis, are often not suitable for use with deep-sea organisms (Feller et al. 1985, Hopkins 1985, Howell et al. 2003), particularly when detrital material forms an important part of the nutrition of the organism.

In the deep sea, all organisms are heterotrophic (except those at hydrothermal vents, cold seeps and minor reducing environments), relying ultimately on surface-derived carbon production for their nutritional requirements. Surface production reaches the seafloor in several forms. However, particles of sizes between 10 and $500 \mu \mathrm{m}$, consisting mainly of aggregates and faecal pellets, provide the main flux of material to the seafloor (Fowler \& Knauer 1986). These particles, known generally as marine snow, are aggregates of many different substances, including a variety of planktonic remains (phytodetritus).

Scanning electron microscope (SEM) and light microscope examinations of the stomach contents of some bathyal and abyssal echinoderms and bivalves have indicated that they ingest a wide variety of phytodetrital material, including diatoms and cocolithophores characteristic of phytoplankton blooms (Tyler et al. 1992a,b, Campos-Creasey et al. 1994). However, in many animals the stomach contents were unrecognisable, due to the degradation of material prior to ingestion and to the animals own digestive processes (Tyler et al. 1992a,b). Identification of the origin of phytodetrital material is therefore not always possible through stomach content analysis.

Investigation of the diet of deep-sea organisms, in particular detrital feeders, thus requires alternative methods of research. Fatty acid biomarkers and isotopic analysis provide such alternative methods and 
are being used increasingly in deep-sea ecology (Iken et al. 2001, Howell et al. 2003). These methods have a number of advantages over stomach content analysis in that (1) fewer samples are required, (2) they provide information on long-term dietary sources (rather than the most recent feeding events) and (3) they are not subject to the biases of stomach content analysis. However, they are unable to identify specific dietary sources and are of greatest use in comparing the diet or trophic position of species.

Pigment biomarker analysis, although frequently used as a dietary tracer in pelagic food webs (Kleppel \& Pieper 1984, Kleppel et al. 1988, Breton et al. 1999, Gasparini et al. 2000, Cotonnec et al. 2001), has not been widely utilised in the deep-sea environment. This is likely to be because the potential use of this technique to deep-sea ecological research has not been widely recognised. The planktonic origin of the principal food resource in the deep sea (marine snow or phytodetritus) suggests that pigment analysis may be a useful tool in tracing its recycling.

All algae contain chlorophyll $a$ as a large fraction of their photosynthetic pigments (Rowan 1989). As a result, chlorophyll a has been widely used as a measure of marine algal biomass and productivity and is one of the most frequently measured biochemical variables in oceanography (Jeffrey et al. 1997). Advances in pigment separation techniques have allowed identification of a wide range of accessory pigments found in photosynthetic organisms. Some of these pigments, or combinations of pigments, are unique to specific algal taxa (Jeffrey et al. 1997) and can be used as biomarkers. Through analysis of the pigments within the stomach content of an organism it is possible to determine the algal components of its diet.

Many abyssal benthic organisms utilise phytodetritus as a food source to some degree (Gage \& Tyler 1991). The question as to if, and how, this resource is partitioned is key to understanding the functioning within the benthic ecosystem. Many deep-sea holothurian species exhibit niche differentiation, and individual species have developed different strategies for exploiting detritus (Billett 1991). Pigment analysis has been applied previously to investigations of deep-sea holothurian diet (Billett et al. 1988). Analysis of chlorophyll and its derivatives in both the sediment and gut content of Oneirophanta mutabilis, a deep-sea holothurian, demonstrated a variable degree of selective feeding in this species (Witbaard et al. 2001). Duineveld et al. (1997) examined the gut content of Psychropotes longicauda from a NE Atlantic abyssal site and found the pigment composition of the gut content to be identical to the surrounding phytodetrital mucus layer content. Wigham (2002), using pigment biomarkers, found that many species of abyssal holothurians feed selectively on separate fractions of the same phytodetrital food resource.

The abyssal porcellanasterid asteroids Styracaster chuni Ludwig (1900) and Hyphalaster inermis Sladen (1883) inhabit similar depth ranges in the Porcupine Seabight and Porcupine Abyssal Plain (3490 to 4877 and 3749 to $4880 \mathrm{~m}$, respectively) and are frequently taken together in trawls (Howell et al. 2002). Both species are mud ingesters, digesting meiofauna, faecal pellets, bacteria and nutrients from organic detritus taken in bulk sediment (Madsen 1961, Shick et al. 1981, Jangoux 1982, Billett 1987). Both species are believed to scavenge on larger animals (Madsen 1961) and may also take up dissolved primary amines through the cribriform organs, as has been suggested for the shallower-dwelling, ecologically similar asteroid species Ctenodiscus crispatus (Shick et al. 1981).

Fatty acid profiles of Styracaster chuni and Hyphalaster inermis demonstrate that they feed on similar resources. Both species rely heavily on bacterial carbon as a source of nutrition (Howell et al. 2003). However, the presence of photosynthetic fatty acid biomarkers, such as polyunsaturated fatty acids (PUFAs), in their body tissues suggests utilisation of seasonally available marine snow. Some small differences in fatty acid composition were evident between the 2 species, suggesting that there may be subtle dietary differences between the species, possibly as a result of food particle selection (Howell et al. 2003). Species of the genus Styracaster have been found to select certain food items (Sokolova 2000) and it is possible that $S$. chuni and $H$. inermis, as with abyssal holothurians, select different food particles from the same phytodetrital resource.

The aim of this study was to investigate possible dietary differences and utilisation of phytodetritus by the mud ingesters Styracaster chuni and Hyphalaster inermis using pigment biomarker analysis.

\section{MATERIALS AND METHODS}

Sampling. The mud-ingesting asteroids Hyphalaster inermis and Styracaster chuni were collected from $4840 \mathrm{~m}$ on the Porcupine Abyssal Plain (Stn 13925\#1) on July 10, 2000, in the NE Atlantic during RRS 'Discovery' Cruise 250. The asteroids were collected in good condition using an otter trawl (Merrett \& Marshall 1981). Upon recovery of the trawl, adult specimens of each species were dissected in a constant temperature laboratory at $4^{\circ} \mathrm{C}$. Stomachs that were full of sediment were extracted from 10 individuals of each species and stored at $-70^{\circ} \mathrm{C}$ for later analysis.

Pigment analysis. Sub-samples of sediment were taken from each stomach and freeze dried. Dried sedi- 
ment was weighed and then prepared for high-pressure liquid chromatography (HPLC) analysis. Pigments were extracted in $5 \mathrm{ml}$ of $90 \%$ acetone. The samples were ultrasonicated for $30 \mathrm{~s}$ and centrifuged at $3000 \mathrm{rpm}(2000 \times g)$ for $15 \mathrm{~min}$. The supernatant was filtered through a $0.2 \mu \mathrm{m}$ nylon filter. Pigments were determined by ion-pairing, reverse-phase HPLC, modified from Mantoura \& Llewellyn (1983), and described by Barlow et al. (1993).

The mobile phase of HPLC comprises a binary eluant system consisting of Eluant A (80\% methanol, $20 \%$ $1 \mathrm{M}$ ammonium acetate), and Eluant B (60\% methanol, $40 \%$ acetone). Ammonium acetate acts as an ionpairing agent. For the analysis, $700 \mu \mathrm{l}$ of $1 \mathrm{M}$ ammonium acetate was mixed with $500 \mu \mathrm{l}$ of pigment extract for $12 \mathrm{~s}$. Of the resulting mixture, $100 \mu \mathrm{l}$ was then injected into an Alltech $3 \mu \mathrm{l} \mathrm{C}-18$ column $(30 \mathrm{~mm} \times$ $4.6 \mathrm{~mm}$ ). A linear gradient from 0 to $100 \%$ Eluant B was created for $10 \mathrm{~min}$, followed by an isocratic stop at $100 \%$ Eluant B for $7.5 \mathrm{~min}$. A second gradient of 2.5 min was used to return to the initial condition of $100 \%$ Eluant A. Separation of the pigments was achieved within $17 \mathrm{~min}$.

Dual channel detection was achieved with a UV6000 photo-diode array detector, and a Spectra System FL3000 fluorescence detector. Chlorophylls and carotenoids were detected by absorbance at $440 \mathrm{~nm}$, while phaeopigments were monitored with the fluorescence detector using an excitation wavelength of $410 \mathrm{~nm}$ and emission at $670 \mathrm{~nm}$. Data collection and integration utilised the Chromquest 3.0 software on a Dell computer.

Pigment identity was secured through co-elution with authentic pigments: chlorophylls $a$ and $b$ and $\beta$-carotene were obtained from Sigma Chemical; chlorophyll $c 2$, chlorophyll $c 3$, peridinin, 19'-butanoyloxyfucoxanthin, fucoxanthin, 19'-hexanoyloxyfucoxanthin, diadinoxanthin, violaxanthin, prasinoxanthin, alloxanthin and zeaxanthin from the Danish Hydraulic Institute (DHI), Denmark. Further confirmation of pigment identity was provided through on-line diode array spectroscopy.

Data analysis. Two methods of analysis were employed. When the pigments could be identified with confidence, their absolute concentration was calculated. However, there were several major compounds (breakdown compounds of chlorophyll and carotenoid pigments) that could not be identified specifically. These unidentified compounds were important components. Therefore, in order not to lose this information when comparing diets of the 2 species, a method of calculating their contribution to the total pigment pool (percentage composition) was used.

Absolute concentrations of identified pigments were quantified using the following equation:
Conc. (ng g ${ }^{-1}$ dry sediment) $=$ peak area $\times$ volume extracted $(\mathrm{ml}) \times 1000$

pigment $\mathrm{RF} \times$ volume injected $(\mu \mathrm{l}) \times$ volume filtered $(\mathrm{l}) \times 0.5$

where RF = retention factor. The percentage composition of individual identified pigments and the major unidentified breakdown products were calculated using the following equation:

The results of both analyses were compared using $\%$ composition $=$

$\frac{\text { peak area }}{\text { total peak area of pigments under consideration } \times 100}$

the Mann-Whitney $U$-test. Further investigation of the data sets was achieved using hierarchical cluster analysis and multi-dimensional scaling (MDS) based on a Bray-Curtis similarity co-efficient with no transformation applied (Clarke \& Warwick 1994).

\section{RESULTS}

Nine pigments were identified from the HPLC chromatograms; the carotenoids diadinoxanthin (retention time [rt] 5.53 to $5.56 \mathrm{~min}$ ), alloxanthin (rt 6.03 to $6.09 \mathrm{~min}$ ), zeaxanthin (rt 6.58 to $6.64 \mathrm{~min}$ ); and the chlorophylls a (rt 9.55 to $9.60 \mathrm{~min}$ ), $b$ (rt 8.61 to $8.66 \mathrm{~min})$, and their breakdown products pheophorbides $a 1$ (rt 3.56 to $3.66 \mathrm{~min}$ ) and $a 2$ (rt 4.51 to $4.62 \mathrm{~min}$ ), and pheophytins $a 1$ (rt 11.14 to $11.24 \mathrm{~min}$ ) and $a 2$ (rt 11.81 to $11.93 \mathrm{~min}$ ). Pigments such as the carotenoids peridinin, 19'-butanoyloxyfucoxanthin, fucoxanthin, 19'-hexanoyloxyfucoxanthin, prasinoxanthin, violaxanthin and $\beta$-carotene, and the chlorophylls $c 1, c 2$ and $c 3$ could not be identified because of the high concentrations of unidentified pigment breakdown products. Baseline resolution of these pigments was poor, thus preventing identification and quantification.

\section{Pigment distribution}

Of the identified pigments pheophorbide a2 was present at the greatest concentrations in the gut sediment of both species (Fig. 1, Styracaster chuni $=15.96 \mathrm{\mu g} \mathrm{g}^{-1}$ sediment and Hyphalaster inermis $=17.06 \mu \mathrm{g} \mathrm{g}^{-1}$ sediment). Pheophorbide $a 1$ was the next most concentrated pigment in both species, but its concentration was less than half that of pheophorbide $a 2$ (Fig. 1, S. chuni $=5.83 \mu \mathrm{g}$ $\mathrm{g}^{-1}$ sediment and $H$. inermis $=6.39 \mu \mathrm{g} \mathrm{g}^{-1}$ sediment). Chlorophyll $b$ was found at the lowest concentrations of all the chlorophyll-type pigments (Fig. 1, S. chuni $=1.08$ $\mu \mathrm{g} \mathrm{g}^{-1}$ sediment and $H$. inermis $=2.01 \mu \mathrm{g} \mathrm{g}^{-1}$ sediment . The carotenoids were present at relatively low concen- 


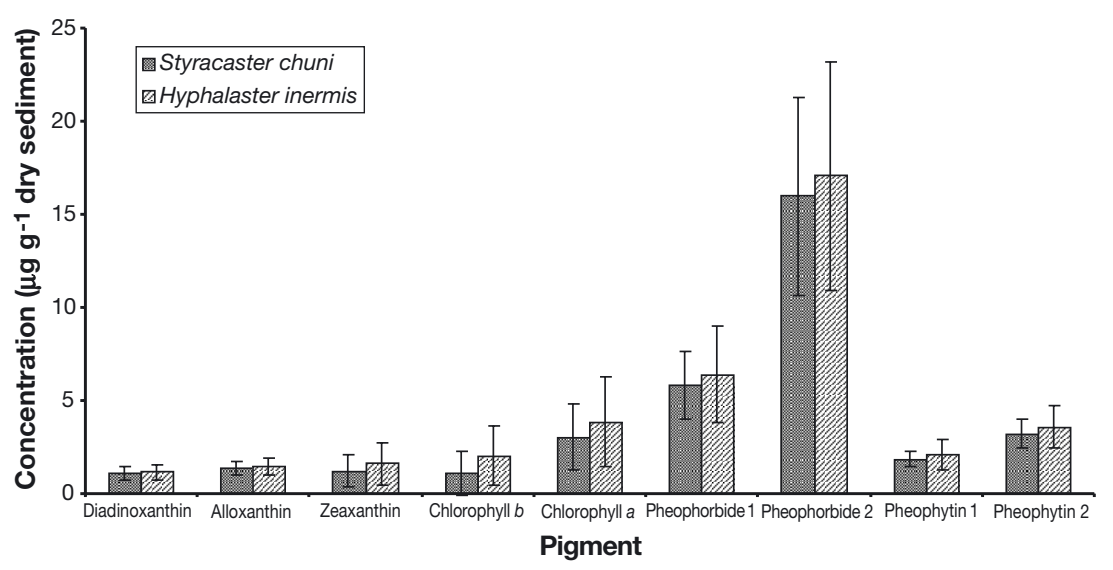

Fig. 1. Styracaster chuni and Hyphalaster inermis. Mean pigment concentration ( $\mu \mathrm{g} \mathrm{g}^{-1}$ dry sediment) of the gut sediments (mean $\pm \mathrm{SD}$ is shown)

ments was not significantly different between species. The only exception to this was chlorophyll $a$, which was present at a significantly greater concentration in the gut sediments of Hyphalaster inermis (Mann-Whitney $U$-test, $\mathrm{p}=0.026)$. However, there was no significant difference between species in the freshness of material in the gut (chlorophyll a:pheophorbide ratio) (Mann-Whitney $U$-test, $\mathrm{p}=0.162$ ).

Analysis of the percentage composition of both identified and unidentified pigments produced the same conclusion: mean percentage composition of pigments did not differ greatly between species (Fig. 2). MannWhitney $U$-tests of the percent-

trations compared to the pheophorbides, varying in concentration between 1.1 and $1.6 \mu \mathrm{g} \mathrm{g}^{-1}$ dry sediment for individual pigments (Fig. 1).

Investigation of the full data set in terms of percentage composition revealed that the unknown pigment breakdown products contribute considerably to the total pigment pool (Fig. 2). Unknown breakdown products 5 and 6 were present in the greatest quantity in both species (Styracaster chuni $=17.4$ and $16.6 \%$, respectively; Hyphalaster inermis = 22.9 and $17.9 \%$, respectively), followed by unknown breakdown products 4 and then 3 (S. chuni $=11.70$ and $8.2 \%$, respectively; $H$. inermis $=12.56$ and $8.34 \%$, respectively. Unknown breakdown product 7 was present at levels similar to the identified carotenoids (Fig. 2), while unknown breakdown products 1 and 2 were only of minor importance to the overall pigment composition (Fig. 2). Complete separation of unknown breakdown products 4 and 5 was not achieved for all samples and so has been displayed as a combined value (Fig. 2). age composition of individual pigments indicated that most pigments were present in similar quantities in both species. The exceptions were again chlorophyll $a$, which contributed a significantly greater percentage to the pigment composition of Hyphalaster inermis (Mann-Whitney $U$-test, $\mathrm{p}=0.017$ ), and unknown breakdown product 5, which was present at a greater percentage in Styracaster chuni (Mann-Whitney U-test, $p=0.009$ ). The percentage composition of zeaxanthin was also found to be significantly different between species (Mann-Whitney $U$-test, $\mathrm{p}=0.026$ ). However, as this was not found to be the case for actual concentration data, it is unlikely to be a reliable difference.

\section{Multivariate statistical analysis}

Hierarchical cluster analysis of quantitative pigment data found 3 clusters at the $85 \%$ similarity level (Fig. 3a). All clusters contained individuals from both

\section{Data analysis}

Initial observations of the raw pigment chromatograms suggested that there was very little difference in gut sediment pigment composition between and within both species. Further investigation of the mean pigment composition for each species also suggested very little difference in composition (Fig. 1). Mann-Whitney $U$-tests of the concentrations of pigments between species confirmed these observations. The concentration of nearly all identified pigments in the gut sedi-

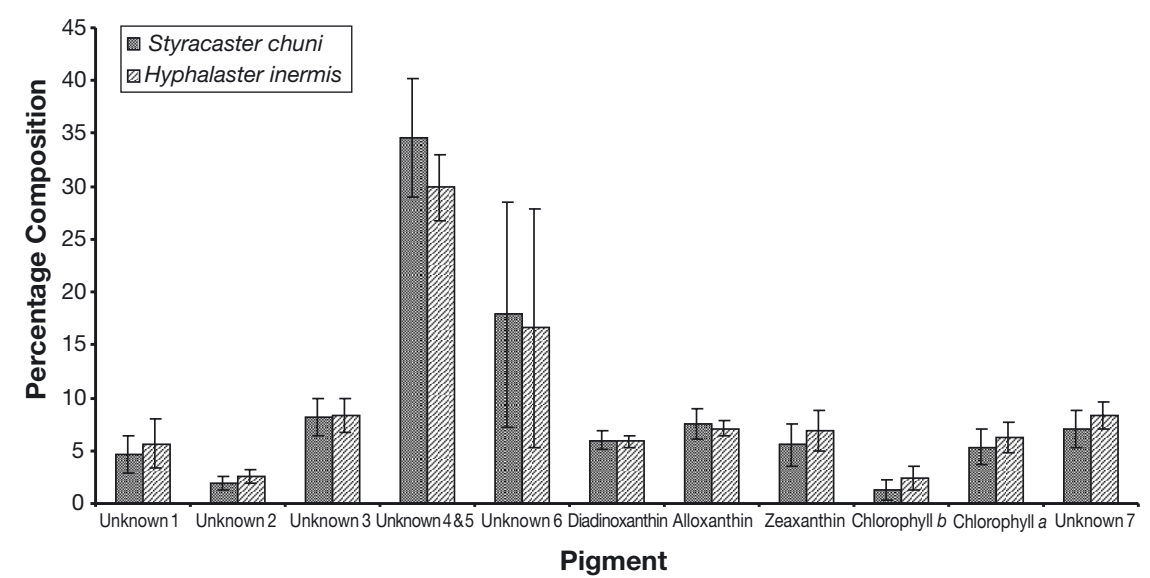

Fig. 2. Styracaster chuni and Hyphalaster inermis. Mean percentage composition of pigments of the gut sediments (mean \pm SD is shown) 


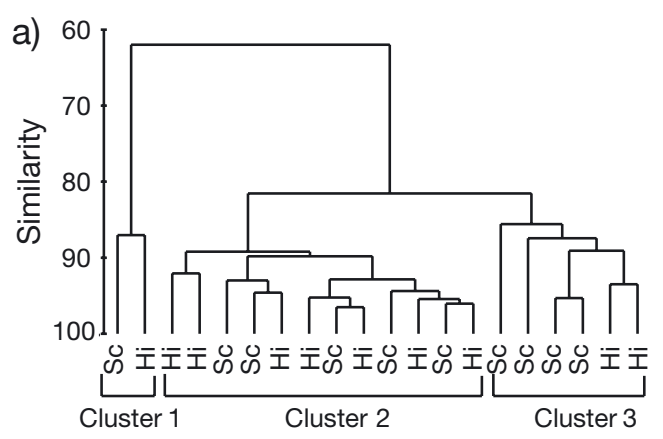

b)

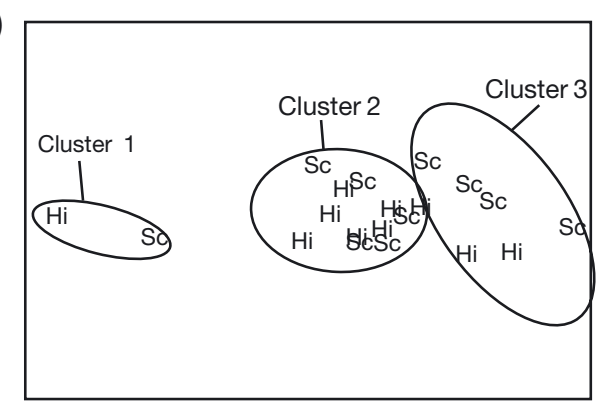

Fig. 3. Styracaster chuni and Hyphalaster inermis. (a) Hierarchical cluster analysis and (b) multi-dimensional scaling plot of the pigment composition (in terms of concentration of pigment) of the gut sediments of each individual $(\mathrm{Hi}=H$. inermis, $\mathrm{Sc}=S$. chuni)

species. MDS of the same data confirmed the presence of all 3 clusters (Fig. 3b, stress value 0.04), although Clusters 2 and 3 were very similar (18.45\% dissimilar). Similarity percentages (SIMPER) analysis (Clarke \& Warwick 1994) of the clusters found that differences in the concentration of pheophorbide a2 was principally responsible for the separation of the clusters. Differences in the concentration of zeaxanthin was also responsible for the separation of Cluster 1 from both Clusters 2 and 3.

Cluster analysis of the full percentage composition data set again found 3 clusters at the $85 \%$ similarity level (Fig. 4a). Clusters 2 and 3 contained individuals of both species, while Cluster 1 contained 2 individuals of Hyphalaster inermis. MDS of the same data set confirmed the presence of all 3 clusters and separation of the clusters was good (least dissimilar groups 20.49\% dissimilar) (Fig. 4b). Unknown breakdown product 4 was principally responsible for the separation of Cluster 1 from both Clusters 2 and 3, while unknown breakdown product 6 was principally responsible for the separation of Clusters 2 and 3.

SIMPER analysis of species groups using, first, quantitative pigment data and, second, semi-quantitative percentage data, confirmed the results of the MannWhitney $U$-tests; no difference in pigments distinguished Hyphalaster inermis from Styracaster chuni.
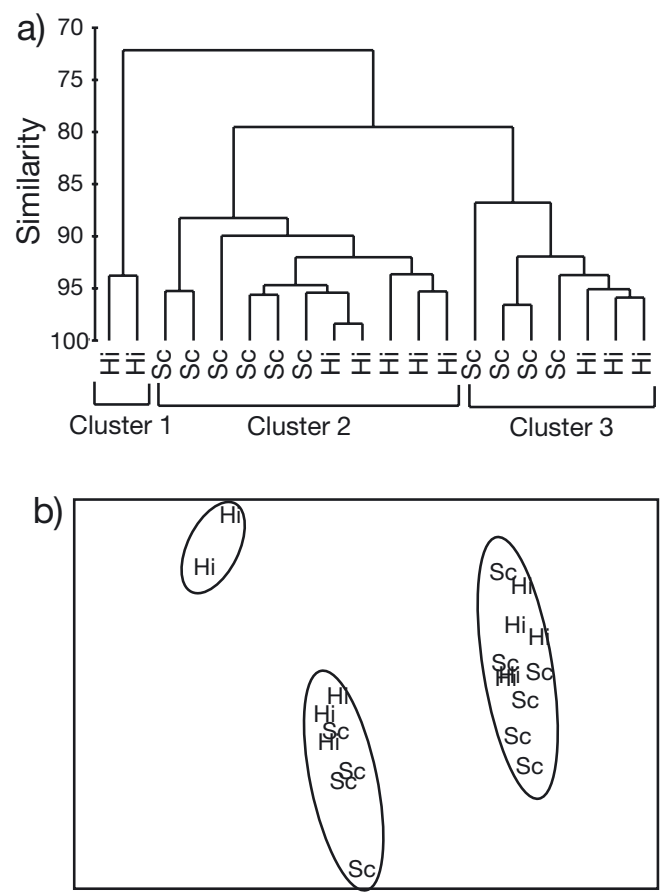

Fig. 4. Styracaster chuni and Hyphalaster inermis. (a) Hierarchical cluster analysis and (b) multi-dimensional scaling plot of the percentage pigment composition of the gut sediments of each individual $(\mathrm{Hi}=H$. inermis, $\mathrm{Sc}=S$. chuni $)$

\section{DISCUSSION}

\section{Similarity in the diet of Hyphalaster inermis and Styracaster chuni}

Styracaster chuni and Hyphalaster inermis are both mud-ingesting species, digesting meiofauna, faecal pellets, bacteria and nutrients from organic detritus taken in bulk sediment (Madsen 1961, Shick et al. 1981, Jangoux 1982, Billett 1987). Both species rely heavily on bacterial carbon as a source of nutrition (Howell et al. 2003). Similarity in the diet of both $S$. chuni and $H$. inermis has been demonstrated previously by similarity in the fatty acid profiles of these species (Howell et al. 2003). There were, however, some small differences in fatty composition, suggesting that there may be subtle dietary differences between the species, possibly as a result of food particle selection (Howell et al. 2003).

Analysis of the chlorophyll and carotenoid pigment composition of the stomach sediments of both species, however, suggests there is little difference in the fraction of phytodetrital material ingested by Hyphalaster inermis and Styracaster chuni. There were small, but significant, differences in the concentration of chlorophyll $a$ in the gut sediment of the 2 species, and in the percentage composition of unknown breakdown prod- 
uct 5, which may be indicative of a subtle difference in particle selection. However, given the similarity in composition of all other pigments, this seems unlikely.

Styracaster chuni and Hyphalaster inermis inhabit similar environments, display similar feeding behaviour and have similar gut morphologies. Therefore, it is not surprising to find little or no difference in the use of phytodetrital resources in their diet. Resource partitioning among deep-sea holothurians occurs by way of habitat selection (Billett 1991), different feeding strategies (Wigham 2002), differences in oral tentacle morphology (McKenzie 1985, 1987, Wigham 2002) and gut diversification (Moore et al. 1995). No such differences are apparent between $S$. chuni and $H$. inermis.

\section{Specific nutritional resources}

The presence of a variety of photosynthetic pigments in the gut sediments of both Hyphalaster inermis and Styracaster chuni confirms the ingestion of phytodetrital material by these species. Phytodetritus consists of many different substances including a variety of planktonic remains such as diatoms, coccolithophorids, dinoflagellates, silicoflagellates, phaeodarians, tintinnids, foraminifera, crustacean eggs and moults, protozoan faecal pellets, nano- and picoplankton cells (chlorophytes, cyanobacteria and bacteria), which when bound together are known as marine snow (Thiel 1979, Billett et al. 1983, Lochte \& Turley 1988). Analysis of specific biomarker pigments can reveal which components of the phytodetrital resource the asteroid species are utilising. However, because certain pigments degrade at a faster rate than others, the quantitative data must be viewed with caution. In addition, certain pigments may have degraded to the point where they can no longer be detected. Therefore, we cannot say, by way of absence, which components of the phytodetrital resource the asteroid species are not using.

Chlorophyll $b$ was present at concentrations similar to the identified carotenoids. Unlike chlorophyll $a$, chlorophyll $b$ is not ubiquitous among photosynthetic organisms. Chlorophyll $b$ is found only in the green algae (Chlorophyceae, Prasinophyceae and Euglenophyta) and symbiotic prochlorophytes (Jeffrey et al. 1997). Previous studies of phytodetritus from 4100 and $\sim 4500 \mathrm{~m}$ on the Porcupine Abyssal Plain have recorded the presence of chlorophyll b (Thiel et al. 1989, DeWilde et al. 1998, Witbaard et al. 2001). Microscopic analysis of Porcupine Abyssal Plain samples suggested that small chlorophytes were responsible for the presence of this pigment (Thiel et al. 1989). The presence of chlorophyll $b$ in the stomach contents of Styracaster chuni and Hyphalaster inermis is therefore likely to be a result of the ingestion of small chlorophytes.
Of the carotenoids, only diadinoxanthin, alloxanthin and zeaxanthin were identifiable, all occurring at similar concentrations (Fig. 3). Alloxanthin is the principal carotenoid of the cryptomonads (Cryptophyta), and the presence of alloxanthin in gut sediment samples suggests ingestion of cryptomonads by Hyphalaster inermis and Styracaster chuni.

Zeaxanthin is a major carotenoid of blue-green algae (Cyanobacteria and Prochlorophyta) and the Rhodophyta. It is also present in the Chlorophyceae, most chrysophytes and the raphidophytes (Jeffrey et al. 1997). Studies of phytodetritus from both the Porcupine Abyssal Plain and the mouth of the Porcupine Seabight found zeaxanthin to be present and attributed this to the presence of cyanobacteria in phytodetritus (Thiel et al. 1989, DeWilde et al. 1998, Witbaard et al. 2001). This was confirmed microscopically for Porcupine Abyssal Plain phytodetritus (Thiel et al. 1989). Pfannkuche \& Lochte (1993) found cyanobacteria in salp faeces from the NE Atlantic and traced the flux of these faeces and associated cyanobacteria from the epipelagic to the abyssal benthos. They suggested that cyanobacteria, and therefore zeaxanthin, may provide a tracer for sedimenting phytodetritus. Zeaxanthin was also found to be the dominant carotenoid pigment in the gut of the holothurian Amperima rosea from the Porcupine Abyssal Plain and its presence was also attributed to cyanobacteria (Wigham 2002).

The large bacterial input to the diet of Hyphalaster inermis and Styracaster chuni as indicated by fatty acid analysis (Howell et al. 2003) is consistent with the ingestion of cyanobacteria by these species. However, zeaxanthin is only present in small quantities, which suggests that cyanobacteria are unlikely to form the bulk of bacterial carbon to the diet (although it is possible that zeaxanthin degrades more rapidly than other pigments and so is present in smaller quantities). Other bacterial sources, such as those inhabiting deep-sea sediments, degrading phytodetritus, possible gut bacterial symbionts and/or subcuticular bacteria, which are present in other echinoderm species (Temara et al. 1991, McKenzie \& Kelly 1994, Ginger et al. 2000), may be more important in the diet of these asteroid species.

Diadinoxanthin is a major pigment in diatoms, dinoflagellates, prymnesiophytes (coccolithophorids) and some chrysophytes (Jeffrey et al. 1997). The presence of this pigment in the stomach contents of both asteroid species could suggest ingestion of any or all of these algal species. Coccolithophorids, dinoflagellates and diatoms have been recorded in phytodetritus from the Porcupine Abyssal Plain and the mouth of the Porcupine Seabight from (1) microscopic examination of sediments (Thiel et al. 1989, DeWilde et al. 1998) and (2) stomach content analysis of holothurians (Tyler et al. 1992b); and from the Rockall Trough from 
the stomach of the bathyal urchin Echinus affinis (Campos-Creasey et al. 1994). Nine different species of coccolith were observed in August phytodetrital mucus samples from $4500 \mathrm{~m}$ on the Porcupine Abyssal Plain, with Emiliania huxleyi contributing by far the greatest component (DeWilde et al. 1998). Diatom species characteristic of the spring bloom were also recorded in August phytodetrital samples from the Porcupine Abyssal Plain (Thiel et al. 1989). It is likely, therefore, that Hyphalaster inermis and Styracaster chuni are ingesting both coccoliths and diatoms as part of their diet.

The chlorophylls $c 1, c 2$ and $c 3$, fucoxanthin, 19'hexanoyloxyfucothanthin, 19'-butanoyloxyfucoxanthin, peridinin, prasinoxanthin and violaxanthin could not be detected as a result of the very high concentration of breakdown products present, which eluted at the same time as these carotenoid pigments. In studies of samples of phytodetritus from the mouth of the Porcupine Seabight, fucoxanthin and 19'-hexanoyloxyfucoxanthin were found to be the dominant carotenoid pigments in the sediment, with peridinin also being important (DeWilde et al. 1998). 19'-hexanoyloxyfucoxanthin is the major pigment of prymnesiophytes (coccolithophores) while fucoxanthin can be indicative of diatoms (Jeffrey et al. 1997, DeWilde et al. 1998). The presence of these pigments in Porcupine Seabight phytodetrital samples suggests that both coccoliths and diatoms would be available as food sources to Hyphalaster inermis and Styracaster chuni. This supports the ingestion of these phytoplankton species, as suggested by the presence of diadinoxanthin in the stomach contents of $H$. inermis and $S$. chuni.

\section{Chloropigments}

Chlorophyll $a$ and its breakdown products pheophorbide $a 1$ and $a 2$ and pheophytin $a 1$ and $a 2$ are not unique to any particular algal group, and so cannot be used as biomarkers. Comparison of the concentrations of these pigments in the stomach content and surrounding sediment could reveal whether Hyphalaster inermis and Styracaster chuni are selecting fresh or degraded material. In this study, sediment samples from the surrounding sediment were unobtainable, and thus such an assessment could not be made. A comparison using sediment pigment data from other studies conducted in the sampling area, at an appropriate time of year (Thiel et al. 1989, DeWilde et al. 1998), suggested active selection of degraded phytodetrital material by both species. This comparison, however, is not entirely appropriate as a result of the annual variability in the input and composition of organic matter to deep-sea sediments.

\section{Conclusions}

Styracaster chuni and Hyphalaster inermis both utilise the same phytodetrital material with no apparent partitioning of those resources. Analysis of specific biomarker pigments suggests that both species ingest small chlorophytes, cryptomonads, cyanobacteria, coccoliths and diatoms as part of the phytodetrital component of their diet.

Given the high dependence on bacterial carbon for the nutrition of these species (Howell et al. 2003), selection of phytodetritus may be a result of the high bacterial growth on phytodetritus and the sediment immediately beneath as compared to the surrounding sediment (Gooday et al. 1990). The minor contribution of photosynthetically derived fatty acids in the diet (Howell et al. 2003) together with the lack of any seasonal reproductive pattern for both species (RamirezLlodra et al. 2002) suggests that seasonally available phytodetritus is unlikely to be a major food source for these organisms.

Acknowledgements. We would like to thank the officers and crew of the RRS 'Discovery', Prof. M. Priede and the Oceanlab in Aberdeen for help in obtaining samples, and Dr. C. Lucas for her advice on the use of pigment analysis. This project is funded by a Natural Environment Research Council (NERC) research studentship (GT04/99/MS/261) awarded to K.L.H.

\section{LITERATURE CITED}

Barlow RG, Mantoura RFC, Gough MA, Fileman TW (1993) Pheopigment distribution during the 1990 spring bloom in the northeastern Atlantic. Deep-Sea Res Part I 40: $2229-2242$

Billett DSM (1987) Benthic results: Echinodermata. In: Roe H (ed) Great Meteor East: a biological characterisation. Institute of Oceanographic Science Deacon Laboratory, Southampton, p 163-178

Billett DSM (1991) Deep-sea holothurians. Oceanogr Mar Biol 29:259-317

Billett DSM, Lampitt RS, Rice AL, Mantoura RFC (1983) Seasonal sedimentation of phytoplankton to the deep-sea benthos. Nature 302:520-522

Billett DSM, Llewellyn C, Watson J (1988) Are deep-sea holothurians selective feeders? In: Burke RD, Mladenov PV, Lambert P, Parsley RL (eds) Echinoderm Biology. Balkema, Rotterdam, p 154-162

Breton E, Sautour B, Brylinski JM (1999) No feeding on Phaeocystis sp. as solitary cells (post-bloom period) by the copepod Temora longicornis in the coastal waters of the English Channel. Hydrobiologia 414:13-23

Campos-Creasey LS, Tyler PA, Gage JD, John AWG (1994) Evidence for coupling the vertical flux of phytodetritus to the diet and seasonal life history of the deep-sea echinoid Echinus affinis. Deep-Sea Res Part I 41:369-384

Clarke KR, Warwick RM (1994) Change in marine communities: an approach to statistical analysis and interpretation. Plymouth Marine Laboratory, Plymouth

Cotonnec G, Brunet C, Sautour B, Thoumelin G (2001) Nutri- 
tive value and selection of food particles by copepods during a spring bloom of Phaeocystis sp. in the English Channel, as determined by pigment and fatty acid analyses. J Plankton Res 23:693-703

DeWilde P, Duineveld GCA, Berghuis EM, Lavaleye MSS, Kok A (1998) Late-summer mass deposition of gelatinous phytodetritus along the slope of the NW European Continental Margin. Prog Oceanogr 42:165-187

Duineveld GCA, Lavaleye MSS, Berghuis EM, de Wilde P, Van der Weele J, Kok A, Batten SD, de Leeuw JW (1997) Patterns of benthic fauna and benthic respiration on the Celtic continental margin in relation to the distribution of phytodetritus. Int Rev Gesamten Hydrobiol 82:395-424

Feller RJ, Zagursky G, Day EA (1985) Deep sea food web analysis using cross reacting antisera. Deep-Sea Res Part I 32:485-497

Fowler SW, Knauer GA (1986) Role of large particles in the transport of elements and organic compounds through the oceanic water column. Prog Oceanogr 16:147-194

Gage JD, Tyler PA (1991) Deep-Sea biology. Cambridge University Press, Cambridge

Gasparini S, Daro MH, Antajan E, Tackx M, Rousseau V, Parent JY, Lancelot C (2000) Mesozooplankton grazing during the Phaeocystis globosa bloom in the southern bight of the North Sea. J Sea Res 43:345-356

Ginger ML, Santos V, Wolff GA (2000) A preliminary investigation of the lipids of abyssal holothurians from the northeast Atlantic Ocean. J Mar Biol Assoc UK 80:139-146

Gooday AJ, Turley CM, Allen JA (1990) Responses by benthic organisms to inputs of organic material to the ocean floor-a review. Phil Trans R Soc Lond Ser A 331:119-138

Hopkins TL (1985) Food web of an Antarctic midwater ecosystem. Mar Biol 89:197-212

Howell KL, Billett DSM, Tyler PA (2002) Depth-related distribution and abundance of seastars (Echinodermata: Asteroidea) in the Porcupine Seabight and Porcupine Abyssal Plain, N.E. Atlantic. Deep-Sea Res Part I 49:1901-1920

Howell KL, Pond DW, Billett DSM, Tyler PA (2003) Feeding ecology of deep-sea seastars (Echinodermata: Asteroidea): a fatty acid biomarker approach. Mar Ecol Prog Ser 255: 193-206

Iken K, Brey T, Wand U, Voigt J (2001) Food web structure of the benthic community at Porcupine Abyssal Plain (NE Atlantic): a stable isotope analysis. Prog Oceanogr 50: 383-405

Jangoux M (1982) Food and feeding mechanisms: Asteroidea. In: Jangoux M, Lawrence JM (eds) Echinoderm nutrition. AA Balkema Publishers, Rotterdam

Jeffrey SW, Mantoura RFC, Wright SW (1997) Phytoplankton pigments in oceanography: guidelines to modern methods. UNESCO Publishing, Paris

Kleppel GS, Pieper RE (1984) Phytoplankton pigments in the gut contents of planktonic copepods from coastal waters off southern California. Mar Biol 78:193-198

Kleppel GS, Frazel D, Pieper RE, Holliday DV (1988) Natural diets of zooplankton off southern California. Mar Ecol Prog Ser 49:231-241

Lochte K, Turley CM (1988) Bacteria and cyanobacteria associated with phytodetritus in the deep-sea. Nature 333: 67-69

Madsen FJ (1961) The Porcellanasteridae: a monographic revision of an abyssal group of seastars. In: Wolff $\mathrm{T}$ (ed) Galathea Rep 4. Danish Science Press, Copenhagen, p 33-174

Mantoura RFC, Llewellyn CA (1983) The rapid determination of algal chlorophyll and carotenoid pigments and their breakdown products in natural waters by reverse-phase high-performance liquid-chromatography. Anal Chim Acta 151:297-314

McKenzie JD (1985) A comparative study of dendrochirote holothurians with special reference to the tentacular functional anatomy. Dissertation Abstracts International Part C 47:646

McKenzie JD (1987) The ultrastructure of the tentacles of 11 species of dendrochirote holothurians studied with special reference to the surface coats and papillae. Cell Tissue Res 248:187-199

McKenzie JD, Kelly MS (1994) Comparative study of subcuticular bacteria in brittlestars (Echinodermata, Ophiuroidea). Mar Biol 120:65-80

Merrett NR, Marshall NB (1981) Observations on the ecology of deep-sea bottom living fishes collected off northwest Africa. Prog Oceanogr 9:185-244

Moore HM, Manship BAD, Roberts D (1995) Gut structure and digestive stratergies in three species of abyssal holothurians. In: Emson RH (ed) Echinoderm research. Balkema, Rotterdam, p 531-537

Pfannkuche O, Lochte K (1993) Open ocean pelago-benthic coupling-cyanobacteria as tracers of sedimenting salp feces. Deep-Sea Res Part I 40:727-737

Ramirez-Llodra E, Tyler PA, Billett DSM (2002) Reproductive biology of porcellanasterid asteroids from three abyssal sites in the northeast Atlantic with contrasting food input. Mar Biol 140:773-788

Rowan KS (1989) Photosynthetic pigments of algae. Cambridge University Press, Cambridge

Shick JM, Edwards KC, Dearborn JH (1981) Physiological ecology of the deposit-feeding sea star Ctenodiscus crispatus - ciliated surfaces and animal-sediment interactions. Mar Ecol Prog Ser 5:165-184

Sokolova MN (2000) Feeding and trophic structure of the deep-sea macrobenthos. Smithsonian Institution Libraries, Washington, DC

Temara A, Deridder C, Kaisin M (1991) Presence of an essential polyunsaturated fatty acid in intradigestive bacterial symbionts of a deposit-feeder echinoid (Echinodermata). Comp Biochem Physiol B 100:503-505

Thiel H (1979) Structural aspects of the deep-sea benthos. Ambio Spec Rep 6:25-31

Thiel H, Pfannkuche O, Schriever G, Lochte $\mathrm{K}$ and 6 others (1989) Phytodetritus on the deep-sea floor in a central oceanic region of the north-east Atlantic. Biol Oceanogr 6: 203-239

Tyler PA, Harvey R, Giles LA, Gage JD (1992a) Reproductive strategies and diet in deep-sea nuculanid protobranchs (Bivalvia, Nuculoidea) from the Rockall Trough. Mar Biol 114:571-580

Tyler PA, Young CM, Billett DSM, Giles LA (1992b) Pairing behavior, reproduction and diet in the deep-sea holothurian genus Paroriza (Holothurioidea, Synallactidae). J Mar Biol Assoc UK 72:447-462

Wigham BD (2002) The 'Amperima Event': analysis of community change in the abyssal Northeast Atlantic Ocean. $\mathrm{PhD}$ thesis, School of Ocean and Earth Science, University of Southampton

Witbaard R, Duineveld GCA, Kok A, van der Weele J, Berghuis EM (2001) The response of Oneirophanta mutabilis (Holothuroidea) to the seasonal deposition of phytopigments at the Porcupine Abyssal Plain in the northeast Atlantic. Prog Oceanogr 50:423-441

Submitted: April 3, 2003; Accepted: November 11, 2003

Proofs received from author(s): January 9, 2004 